\title{
Is the concept of the cultural district appropriate for both analysis and policymaking? Two cases in Northern Italy
}

\author{
Davide Ponzini a, ${ }^{\text {a, }}$ Silvia Gugu ${ }^{\text {b }}$, Alessandra Oppio ${ }^{\text {a }}$ \\ ${ }^{a}$ Department of Architecture and Urban Studies, Politecnico di Milano, Via Bonardi 3, 20133 Milano, Italy \\ ${ }^{\mathrm{b}}$ Department of Architecture, Built Environment and Construction Engineering, Politecnico di Milano, Via Bonardi 9, 20133 Milano, Italy
}

Received 8 October 2013

Received in revised form date 4 May 2014

Accepted 6 May 2014

Available online 3 June 2014

\section{Introduction}

In the last 15 years, greater attention has been given to the role of cultural heritage and creative industries in fostering innovation and economic development in contemporary cities and regions. From different disciplinary points of view, scientific journals have published special issues on this topic. One can mention, for example, City, Culture and Society (Colbert, 2011; Stolarick, Hracs, \& Florida, 2010); Urban Studies (Miles \& Paddison, 2005), Local Economy (Wilks-Heeg \& North, 2004) and International Journal of Cultural Policy (Gibson \& Stevenson, 2004). A wide set of policies have been adopted internationally (Council of The European Union, 2007; European Commission, 2010; UNDP/ UNCTAD, 2010; UNESCO, 2006). Most notably, the European Commission's Creative Europe program was

\footnotetext{
* Corresponding author. Address: Department of Architecture and Planning, Politecnico di Milano, Via Bonardi 3, 20133 Milano, Italy. Tel.: +39 02 23995427; fax: +3902 239935 .

E-mail addresses: davide.ponzini@polimi.it (D. Ponzini), silvia.g.wencel@gmail. com (S. Gugu), alessandra.oppio@polimi.it (A. Oppio).
}

announced in late 2011 (European Commission, 2013). It aims at fostering cultural production and diversity in Europe by providing financial and informational support. The UNCTAD Creative Economy Program was started in the mid 2000s with the purpose of supporting governments' action towards creative production and economic development, building consensus and advocacy networks for this sector. National governments in most Western countries have undertaken similar initiatives.

Under this broad umbrella, the pressure for evidencebased policy has fueled an increased interest in mapping the existing urban and regional concentrations of cultural production and consumption (i.e. cultural mapping - a way to collect quantitative and spatial data in support of cultural and creative industries policies; Matarasso, 1999; Pratt, 2004). In Italy, peculiar urbanization patterns and the tight relationship of cultural heritage with the creative industries (Bertacchini \& Borrione, 2013; Lazzeretti, Boix, \& Capone, 2008), have created a distinct framework for cultural mapping, gravitating around identifying localized cultural ecosystems broadly labeled as "Cultural Districts" (Santagata, 2002), from now shorten as CD. 
Specifically the domination of CD discourse in Italian cultural policy is paralleling a significant number of international policy measures and academic contributions that have evolved around the concepts of "cultural cluster" and "cultural quarters". These terms are used for both detecting and analyzing the spatial organization of cultural production and consumption, as well as for designing policy measures for supporting them, enhancing their spillover effects, and even for creating new organizations and agglomerations. The differences between the two acceptations of the cultural cluster concept have not been thoroughly clarified in the international debate. Our work intends to question whether it is appropriate to couple these two significantly different meanings and it calls for greater consideration.

After a review of the current literature on CDs and clusters, their analytical and policy approaches, the paper describes the Italian cultural policy context, in which a rich and widespread material and immaterial heritage is considered a natural place for linking cultural policy to local development initiatives. Then, after explaining the methodological approach, the paper analyzes two CD initiatives in Northern Italy: one relied mainly on the mapping and analysis of existing cultural assets and was carried out by the Veneto Regional Government, and the other coupled a more interactive approach (including the use of grants) for promoting CDs in non-metropolitan areas of Lombardy.

Of course it is not possible to generalize the findings of two case studies only, but, according to this evidence, the authors maintain that it is not appropriate to use the concept of $C D$ as an analytical unit and a ready-made policy measure, at least with reference to the Italian context. In order to improve the debate on CD analysis and policymaking, significant consideration should be given to critical policy conditions, such as the agenda, timeframe and political interaction implied, the type of knowledge produced and used in the policymaking and implementation process.

\section{Analyzing and planning Cultural Districts: the current debate and its limitations}

The growing political attention paid to the clustering of cultural and creative industries in the European policy context has not been easily transferred to national policy arenas and practice. Instead, the regional and urban levels have emerged as a more suitable base for such policies (Andres \& Chapain, 2013; Chapain, Clifton, \& Comunian, 2013), precisely due to the propensity of cultural activity to cluster at urban and regional scales. Recent contributions have shown the importance of explicitly relating cultural clusters to economic development (Cooke and Lazzeretti, 2008; Scott, 1997, 2004). The terms used to label the models describing spatial organization of cultural production and consumption are not particularly useful in classifying the differences among the so-called cultural clusters, districts or quarters. They are oftentimes interchanged to describe similar phenomena (Cooke, 2005). Nonetheless, these labels provide interesting insights into the spatial organization of cultural institutions and production, making more evident and relevant links between cultural assets, creative activity and economic development, and urban-regional transformations.
In Walter Santagata's definition (2002, 11), CDs are described as "geographically clustered networks of interdependent entities defined by the production of idiosyncratic goods based on creativity and intellectual property". Similarly, while international definitions refer to a CD as an area of a city, or a neighborhood, other Italian definitions emphasize the relational aspect of CDs (Valentino, 2003), and as a "mix of top-down planned elements and emergent, self-organized activities" (Sacco, Tavano Blessi, \& Nuccio, 2008, p. 3). The term Cultural District has been used to designate various types of cultural clusters, from neighborhood level (Mommaas, 2004; Stern \& Seifert, 2007, 2010) to city-wide (Frost-Kumpf, 1998) and regional networks (Le Blanc, 2010). Several authors have highlighted the need for greater conceptual clarity by making distinctions and classifications of CDs: Cooke and Lazzeretti (2008) underscored the need to conceptually distinguish between creative businesses clusters and cultural amenity concentrations; Stern and Seifert (2007) pointed out the difference between 'natural' Cultural Districts and policydriven ones. Walter Santagata (2002) distinguished between industrial, institutional, museum and metropolitan CDs.

In general terms, the academic literature has examined CDs by following two broad directions: one aimed at mapping and explaining the clustering of cultural industries or activities (e.g.: Cooke and Lazzeretti et al., 2008; Lazzeretti et al., 2008; Lorenzini, 2011; Pratt, 2008; Santagata, 2002; Scott, 1997) and the other concerned with urban planning and cultural policy interventions for the stimulation or creation of cultural clusters as areas for cultural consumption and production (e.g.: Frost-Kumpf, 1998; Le Blanc, 2010; Mommaas, 2004; Sacco et al., 2008; Stern \& Seifert, 2010). The two acceptations are often tacitly adopted and explored across policy and geography studies, without pointing out the similarities, differences and implications that mapping has for policy making and vice versa. This is particularly evident if one considers the ways the same term is used in distant contexts such as Northern America, Europe and Asia. For example, in Baltimore, Maryland, a set of public, private and nonprofit organizations jointly created the Mount Vernon CD in order to revitalized the historic city center by levering the great concentration of cultural amenities and historic sites (Ponzini, 2009). In Europe, many cities like Vienna (Cultural Quarter), Berlin (Museum Island) and others, have fostered the clustering of museums and cultural amenities in given areas of the city following the district rationale which in most cases started from cultural mapping (for significant set of cases, see: Roodhouse, 2010). Rising capital cities in the Gulf area as well as in South East Asia have been deliberatively using this label as a ready-made policy formula for creating new venues for global cultural tourism (most notably: the West Kowloon Cultural District in Hong Kong - see Raco \& Gilliam, 2012 - or the Saadiyat Island Cultural District in Abu Dhabi, UAE - see Ponzini, 2011).

In this framework, among the different analytical techniques, cultural mapping has been instrumental in identifying agglomerations of cultural activity and assets, or what Stern and Seifert (2010) would call "natural Cultural Districts". It is also widely acknowledged as a step in the cultural planning process (Evans \& Foord, 2008; Higgs \& 
Cunningham, 2008; Lee \& Gilmore, 2012) and - more interestingly for the aims of this paper - increasingly as a policy measure in itself (Lee \& Gilmore, 2012; BOP Consulting, 2010; Pratt, 2004; Tepper, 2002). Depending on the focus - whether place-based, industry-based or targeting the creative labor force, or 'creative class' - one can distinguish different approaches to cultural mapping. Some rely on inventorying cultural assets (Evans \& Foord, 2008; Stern \& Seifert, 2010); others on industry-occupational statistics (DCMS, 1998); while systemic mapping seeks to capture the whole 'production chain' of the cultural and creative economy (Pratt, 1997). One can notice a growing sophistication of the tools involved in mapping, such as participatory Geographic Information Systems (Gibson, Brennan-Horley, \& Warren, 2010) or Social Network Analysis. This variety makes "cultural mapping" at the same time a somehow fuzzy concept and a policy practice which can adapt to different circumstances.

The recent Cultural District and cultural cluster literature that has focused on policy and planning has highlighted an array of variables that play a role in Cultural District policy making. In synthesis, it shows the importance of stakeholder coalitions and policy networks (Mizzau \& Montanari, 2008; Moon, 2001); of diverse and stable funding sources (Brooks \& Kushner, 2001; Ponzini, 2009); some authors find that leadership and the clarity of the Cultural District objectives influences their success (Brooks \& Kushner, 2001), others note the bottom-up nature and the volatility of cultural cluster dynamics (Mommaas, 2004; Pratt, 2012), and recall the non-linear nature and path dependency of cultural production sys-tems (Comunian, 2011).

In contrast with the vivid debate that surrounds regional industrial or high tech cluster policies in Europe, the strategies for regional systems and clusters of cultural production and consumption have received far less attention (Andres \& Chapain, 2013). Yet putting cultural clusters in a regional perspective reveals their importance as platforms for inter-municipal organizational cooperation and offers insights into their global positioning (Scott, 2004). More attention has been given to the regional dimension of cultural clusters through the exercise of cultural mapping (e.g.: DCMS, 1998; Scott, 1997; Creative City Network of Canada, 2006; Lazzeretti et al., 2008; Wojan, Lambert, \& McGranahan, 2007), which has often revealed their reliance on multi-scalar networks (Pratt, 2004), territorial diffusion (Lazzeretti et al., 2008; Wojan et al., 2007) and path dependency (Bertacchini \& Borrione, 2013). The paper considers two cases of cultural district policymaking at the regional scale, contributing with further evidence to this debate.

\section{Italy as a laboratory for Cultural Districts}

Thanks to its rich heritage, Italy is considered a natural place for linking cultural policies and development policies (De Luca \& Rotondo, 2005). In addition, Italian cultural heritage has historically had high economic and symbolic relevance and strong relationships to creative production (Santagata, 2009). The geographic concentrations of small and medium size enterprises and cooperating cultural producers have been historically characterized by proximity relationships and efficiency advantages (e.g. human capital development, knowledge spillovers) and the creation of common material and immaterial infrastructures, as one can see in most Italian historic city centers.

Following the long tradition of industrial district studies (Bagnasco, 1977; Beccattini, 2003 among others), Italian scholars were quick to embrace the concept of the $C D$ in parallel with the international debate on cultural clusters. On many occasions, these intellectuals have also served as consultants for public and nonprofit organizations at the national, regional and local level. Italian policymakers approached the $\mathrm{CD}$ issue as a great opportunity and to some extent as a priority, given the amount and quality of both material and immaterial heritage that many Italian cities and towns have both in urban and rural areas.

The general importance of industrial districts in the Italian productive landscape during the last decades of the 20th century also created a favorable legislature basis at the national and regional level. ${ }^{1}$ In lack of a policy for crea-tive industries, many $C D$ initiatives have followed this logic: studies and analyses at regional or provincial level (e.g. in Lazio, Lombardy, Sicily, Veneto, Puglia, Trentino-Alto Adige, Basilicata) have identified the areas demonstrating a high presence of cultural resources and complementary cultural specialization; they have mapped systemic relationships, benchmarked cultural and natural assets against national average, and then sought to develop CDs. In 2002, ACRI (an organization that represents the Savings Banks and the Banking Foundations) launched the 'Sviluppo Sud' Project, aimed at developing CDs in Southern Italy. This call for projects directed 26 Million Euro to the Southern regions for integrating heritage conservation initiatives into wider economic and spatial planning frameworks. It supported local partner-ships and networks across industrial and creative sectors. Although the impact of this initiative did not have significant public exposure, similar initiatives mushroomed in the fol-lowing years, though with a smaller scale and scope.

Despite the heterogeneity of these initiatives, the prevalence of regional visions and the concern with non-metropolitan, even rural, CDs are particularly distinctive. This suggests that, when matured, the Italian CD experience could address two major gray areas in the international understanding of cultural economies: the qualitative development effects of CDs going beyond quantitative economic measures and the role of non-metropolitan territories in the cultural creative economy. These aspects, which received limited attention in the international literature, have been in fact theorized by Italian scholars (e.g.: Bertacchini \& Santagata, 2012; Lorenzini, 2011; Sacco, Ferilli, \& Tavano Blessi, 2012).

In 2008, the Research Board of the Italian Ministry of Cultural Heritage (MiBAC) coordinated by Santagata issued a systematic analysis of creativity and cultural production in Italy: 'White Paper on Creativity' (Santagata, 2009) sparking significant debate. The study achieved a detailed description of the Italian creative and cultural production processes, a better definition of cultural industries for statistic purposes and a comparison between the international

\footnotetext{
1 Law 317/1991, Decreto Guarino of 1993, Law 140/1999, and a 2001 resolution of the Inter-ministerial Committee for Economic Planning aimed at providing criteria for the identification of industrial districts, pertaining to density, specialization and size of businesses. Law 266/1997 introduced for the first time economic incentives for their support, primarily related to financing ICT infrastructures.
} 
and national policy contexts. The research distinguishes between two models of creativity: one oriented towards innovation, relying on new technologies, the Internet economy and communications, and one towards social quality, nurtured by culture, local socioeconomic system, and CDs. The latter is deemed prevalent in Italy and hence is thoroughly elaborated on throughout the book, as well as built upon in the concluding policy recommendations for a 'Creative Italy'.

Along with this pool of theoretical knowledge and the considerable effort invested in identifying potential CDs and appropriate strategies to consolidate them, many initiatives have started at the regional level. This paper compares two regional initiatives, one currently being implemented in Lombardy and one undertaken in the Veneto Region.

\section{Research questions and methodology, case study selection}

Aside from the examples and considerations described above, this paper does not aim to provide a systematic analysis of existing or planned Italian CDs. Two significant but quite diverse examples are used for showing the state of the art and for critically discussing the central research question of the paper, namely the difference between analytical and policy-oriented approaches to CDs.

The study of the policies undertaken in two Northern Italian Regions aimed at analyzing or promoting spatial systems for heritage preservation and creative production provided an overview of the institutional setting in relation to local development processes, the main actors in this arena and diverse governance approaches. Each case was described in its context at different scales and under different variables: policy context, location, financial investment and cultural policy contents (cultural production per se or the relationships implied by these spatial organizations); definition of the spatial organization of cultural production (boundaries, type of cultural activities or places included); feasibility and time-frame; networking and local actors mobilization; knowledge production and management (e.g. scientific knowledge or usable knowledge); funding and monitoring (in itinere and ex-post evaluations). ${ }^{2}$

In 2005, the Veneto Region started a systematic study of spatial systems for heritage preservation and cultural production throughout the regional territory, the so-called Distretti Culturali Evoluti (DiCE), or system-wide Cultural Districts. This is an advanced experience in the analysis of district-like relationships and their potential, though having little implications on local economic development and cultural or creative policymaking.

The Lombardy Region has been experimenting with local systems for cultural preservation as well. The Cariplo Foundation, a major Banking Foundation based in Lombardy, supported the creation of integrated cultural systems through research, promotion and funding (2004-2006). These acted as a stepping stone for a more audacious CDs

\footnotetext{
2 The research was primarily based on secondary sources, i.e. documentary sources regarding the examined policies, official records, internal reports, press reviews, existing data collections. Six semi-structured phone and face-to-face interviews with different key informants.
}

program 'Cultural Districts -Drivers for Local Economic Development' (2005-2014) throughout the region.

The cases of the Veneto and Lombardy Regions and their comparison are relevant to both the national and international debates, as they:

- both have a regional scope and show peculiar spatial features and governance dynamics;

- have different promoters: one project is carried out by the Regional Government and one by a nonprofit organization (albeit partnering with several public and private parties);

- target both urban and rural CDs (while most of the international debate considers urban environments only);

- show peculiar features of Italian interpretation of and experimentation with CDs;

- provide concrete examples of two different approaches to CDs, one has mainly developed analytical instruments and the other financing policy measures according to analyses and interaction with local stakeholders;

- have a strong knowledge base for detecting CDs and for programming new interventions.

\section{The Veneto region Cultural Districts 'DiCE'}

In the context of the Interreg Operational Programme Italy-Slovenia 2000-2006, the Veneto Region commissioned to the IUAV University of Venice a study on the entire regional territory with the aim of fostering local economic development according to the model of the so-called System-Wide Cultural District (for a detailed explanation see: Sacco, Ferilli, \& Lavanga, 2007; Sacco et al., 2012). The Italian acronym was DiCE: Distretti Culturali Evoluti. The program aimed at: identifying homogeneous areas in terms of current and potential cultural supply and degree of specialization in creative production; involving local actors for the definition of shared development strategies for coordinating stakeholders and attracting external funds; encouraging cultural and creative clustering in the Veneto Region. The initiative was financed by the EU (35\%), national (35\%) and regional government (15\%) and other public funds (10\%).

\section{Analytical tools}

The analysis of the cultural potential of the Veneto Region was based on accurate descriptions and mapping of cultural activities and facilities and the regional planning system of Veneto's socio-economic features. The study has identified emerging clusters of cultural activities, according to twelve strategic development factors grounded on the culture-led approaches (Sacco \& Crociata, 2012; Sacco \& Tavano Blessi, 2005; Sacco et al., 2007). These analytic categories were combined with those regarding complementary cultural and socio-economic activities in order to better explore the relationships among cultural and socioeconomic activities.

\section{Data collection}

The data were collected from different sources covering the whole region and concerned mainly: Tangible cultural 
infrastructure (so-called 'containers'), represented by existing or potential cultural facilities; Intangible cultural infrastructure (so-called 'contents'), such as regular and continuous cultural activities and events; Tourism infrastructure and activity and Ongoing cultural and touristic programs and projects. Alongside these main data other demographic trends, educational institutions, transport links and local stakeholders were captured

- Transport systems

- Existing economic activities

- Institutional and legislative characteristics of the area

- Stakeholders already working at different levels (municipal, county, regional) for enhancing the cultural and the socio-economic development

\section{Spatial analysis of boundaries and spatial configuration}

The output (2.042 containers and 2.507 cultural activities) of the survey was shared with local stakeholders, which had actively cooperated with the research group. The containers and contents were mapped through the use of a Geographic Information System, revealing a spatial distribution pattern that, in most cases, was independent from the Provincial and Municipal administrative borders. One of the first insights from the map is the high degree of territorial diffusion of the regional cultural supply: $85 \%$ of the municipalities have at least one container/content. On this analytic basis, twelve cultural clusters were identi-fied (listed in Table 1). These were divided into three main categories defined by the typology and the degree of heterogeneity of cultural infrastructure.

\section{Cultural market and feasibility studies}

The research has mainly focused on the cultural vocation of each district, without explicitly considering the cultural demand. The cultural vocation has been defined through a SWOT analysis, using the Topological Weighted Centroid software, which has processed 80 socio-economic variables from the Italian National Institute for Statistics in addition to the data about cultural infrastructures and activities. General recommendations for a balanced development of each district derived from the data collected. The importance of connecting existing material and intangible cultural resources in a system is stated, without providing economic and financial profile of the needed investments over time.

\section{Process management and involvement of local actors}

The fact that cultural heritage is widespread in the Veneto region is considered as a catalyst for innovation and development processes grounded on the renewal of mature products and services (KEA, 2009; Lazzeretti, 2012). The most-advanced experiences - DiCE 6 Veneto Orientale and DiCE 10 Basso Adriatico - had involved a great number of local actors among policy-makers and cultural operators, playing a crucial role in conveying the macro discourse of cultural clusters and culture-led development in Veneto (Calcagno, Lusiani, \& Panozzo, 2012), but they did not go beyond an in-depth and systematic survey of their cultural heritage conditions, competences and creative expressions. Furthermore, the acknowledgment of this complex network of resources is not followed by the definition of any agency or specific policy measures. If on the one hand this process has produced accurate knowledge, it could not directly spark policy measures. Specific cultural and local development effects were not detected by the Regional administration.

\section{Funding and monitoring}

The Veneto Region did not provide any direct financial incentives for the development of CDs, nor is it monitoring the activities in corresponding areas.

\section{The Lombardy region cultural district program}

In Lombardy, the initiative 'Cultural Districts -Drivers for Local Economic Development' was undertaken by the Cariplo Foundation in 2005. It aimed at stimulating local economies by co-funding and institutionalizing CDs for the integrated management of heritage, cultural activities and tourism. The Foundation assumed that investments in heritage preservation would generate positive spillover effects, if accompanied by the construction of district-like relationships. To this end, they have programmed matching grants of a maximum 4 million euro per project for a CD and an integrated plan. The program was directed towards the non-metropolitan areas of the Region, which could benefit most from the size and scope of the program.

The stated goals of the program were to (1) incentivize long-term visions; (2) promote better communication among the actors in the cultural sector; (3) support the dialog among the cultural, administrative and productive systems; (4) reinforce quality-oriented decisional processes (5) plan the sustainability of cultural interventions

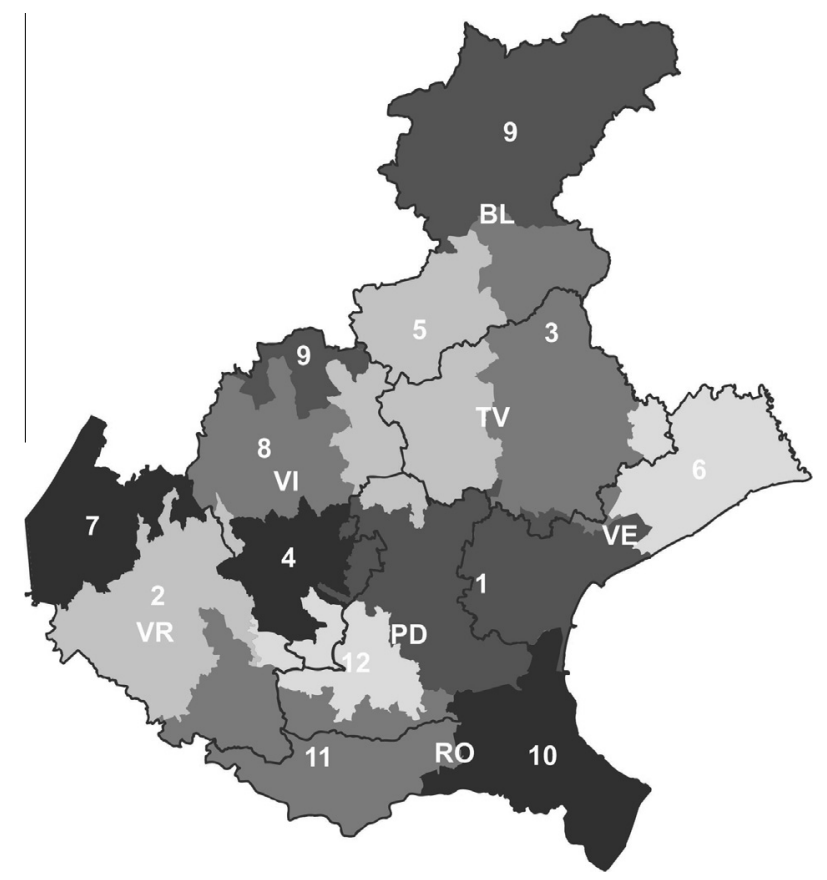

Fig. 1. The 12 Cultural Districts identified in the Veneto Region, overlaid upon the 7 provincial boundaries. 
Table 1

The Cultural Districts of the Veneto Region. Description, vocations, containers and contents.

\begin{tabular}{|c|c|c|c|c|}
\hline Name & Description & Vocation & Containers & Contents \\
\hline $\begin{array}{l}\text { 1. Central } \\
\text { system } \\
\text { Padua- } \\
\text { Venice }\end{array}$ & $\begin{array}{l}\text { DiCE } 1 \text { includes a vast plain and the Venice lagoon. It is the } \\
\text { main regional center for economic and financial services, } \\
\text { tertiary and educational sectors and represents a key } \\
\text { multimodal transportation axis for NE Italy. It has a wide } \\
\text { variety of national and international cultural activities, } \\
\text { containers and institutions }\end{array}$ & $\begin{array}{l}\text { The district has a leading role in the region. It could compete } \\
\text { better at global level, by controlling mass tourism in its two } \\
\text { major cities, and diversifying creative and cultural } \\
\text { production }\end{array}$ & 578 & 773 \\
\hline 2. Verona & $\begin{array}{l}\text { Verona is an important infrastructural node for NW Italy. } \\
\text { This district is characterized by a variety of specific } \\
\text { industries and services (e.g. fashion, logistics, multimedia, } \\
\text { wine production) and a high density of cultural industries. It } \\
\text { is however fragmented by urban/rural disparities }\end{array}$ & $\begin{array}{l}\text { DiCE } 2 \text { has well developed cultural and creative industries } \\
\text { and a solid economic base. The strategy aims to overcome } \\
\text { the one-shot approach to cultural events, and direct cultural } \\
\text { investments towards periphery areas, to use the stock of } \\
\text { abandoned industrial space }\end{array}$ & 155 & 314 \\
\hline $\begin{array}{l}\text { 3. Dorsale } \\
\text { Belluno- } \\
\text { Treviso }\end{array}$ & $\begin{array}{l}\text { The Treviso area has a polycentric organization and a } \\
\text { widespread culture of well-living, but it could be threatened } \\
\text { by the limited long-term strategic vision }\end{array}$ & $\begin{array}{l}\text { The major potential of this area is the polycentric character } \\
\text { combined with a strong civic tradition and a robust system } \\
\text { of local identities. The district strategy deems coordination } \\
\text { key to further development }\end{array}$ & 322 & 419 \\
\hline $\begin{array}{l}\text { 4. Vicenza and } \\
\text { Basso } \\
\text { Vicentino }\end{array}$ & $\begin{array}{l}\text { DiCE } 4 \text { has a valuable natural heritage. This tends to be } \\
\text { neglected in favor of a focus on an economy based on } \\
\text { longstanding traditional industrial districts }\end{array}$ & $\begin{array}{l}\text { DiCE } 4 \text { proposes an innovative cultural development model, } \\
\text { taking advantage of the underused industrial spaces for } \\
\text { creative activities and social services }\end{array}$ & 111 & 117 \\
\hline $\begin{array}{l}\text { 5. Sistema } \\
\text { cerniera }\end{array}$ & $\begin{array}{l}\text { The district includes municipalities in the provinces of } \\
\text { Vicenza, Treviso and Belluno. It is a polycentric system, } \\
\text { characterized by promising dynamics in the design industry }\end{array}$ & $\begin{array}{l}\text { Possible threats include a relative homogeneity in terms of } \\
\text { socio-economic development, and areas characterized by } \\
\text { few economic activities and depopulation. The strategy aims } \\
\text { to balance activities between central and peripheral areas }\end{array}$ & 198 & 173 \\
\hline 6. East Veneto & $\begin{array}{l}\text { DiCE } 6 \text { is organized around the two poles of Portogruaro and } \\
\text { San Dona di Piave, Heritage, tradition and seaside tourism } \\
\text { define the economy of the district. This could hinder } \\
\text { opportunities for experimentation and the development of } \\
\text { human capital }\end{array}$ & $\begin{array}{l}\text { Seaside tourism services can be integrated with cultural and } \\
\text { entertainment activities. The strategy considers the area's } \\
\text { favorable location for cultural and economic connections to } \\
\text { Eastern Europe }\end{array}$ & 73 & 137 \\
\hline $\begin{array}{l}\text { 7. Garda and } \\
\text { Lessinia }\end{array}$ & $\begin{array}{l}\text { DiCE } 7 \text { comprises part of the Garda Lake and hills. The local } \\
\text { economy is based on tourism, viticulture, mining. Despite } \\
\text { the importance of tourism, cultural industries are } \\
\text { underdeveloped. Short-term exploitation risks } \\
\text { compromising the sustainability of tipical productions (i.e. } \\
\text { wine) }\end{array}$ & $\begin{array}{l}\text { Coordination of local stakeholders could overcome the lack } \\
\text { of one strong urban center. Development opportunities can } \\
\text { arise from the new cultural-creative activities cooperating or } \\
\text { competing with the Verona area }\end{array}$ & 29 & 51 \\
\hline $\begin{array}{l}\text { 8. Alto } \\
\text { Vicentino }\end{array}$ & $\begin{array}{l}\text { DiCE } 8 \text { has important natural ecosystems. Despite its } \\
\text { marginal location, it excels in organizing local networks, } \\
\text { partly thanks to a dynamic base of knowledge economy } \\
\text { firms. Even in the absence of institutions of primary } \\
\text { importance, there is a high level of cultural vitality among } \\
\text { the young generation }\end{array}$ & $\begin{array}{l}\text { In this favorable context, the main weakness is the uncertain } \\
\text { future economic role of culture, innovative enterprises and } \\
\text { creative industries. A greater effort to coordinate local } \\
\text { governments and the private sector can strengthen the } \\
\text { system }\end{array}$ & 114 & 88 \\
\hline $\begin{array}{l}\text { 9. Alto } \\
\text { Bellunese } \\
\text { and } \\
\text { Altopiano } \\
\text { di Asiago }\end{array}$ & $\begin{array}{l}\text { The district includes the northern parts of Belluno and } \\
\text { Vicenza provinces. These areas have similar features: low } \\
\text { population density, younger generation migration trend, and } \\
\text { an attractive landscape that draws tourists. In the Middle } \\
\text { Cadore area there is an active and dynamic entrepreneurial } \\
\text { class }\end{array}$ & $\begin{array}{l}\text { A stock of military and industrial buildings could be } \\
\text { converted to host cultural and creative industries. The } \\
\text { opportunity to develop cross-border territorial partnerships } \\
\text { and cooperation could attract further resources }\end{array}$ & 119 & 102 \\
\hline $\begin{array}{l}\text { 10. Basso } \\
\text { Adriatico }\end{array}$ & $\begin{array}{l}\text { The area lies between the Adriatic coast and the Po River, } \\
\text { overlapping the Po Delta, one of the most important } \\
\text { wetlands in Europe. DiCE } 10 \text { is one of the most critical areas } \\
\text { of the entire region from the point of view of socio-economic } \\
\text { innovation. Its location is marginal and there is little cultural } \\
\text { initiative. }\end{array}$ & $\begin{array}{l}\text { Developing sustainable tourism is a viable alternative, but } \\
\text { not sufficient to modify the area's socio-economic dynamics. } \\
\text { Reduced cultural activity and low cultural entrepreneurship } \\
\text { constitute critical issues. The cities of Adria and Chioggia } \\
\text { could take the lead in cultural policy making }\end{array}$ & 50 & 53 \\
\hline $\begin{array}{l}\text { 11. Rovigo and } \\
\text { Basso } \\
\text { Padovano }\end{array}$ & $\begin{array}{l}\text { DiCE } 11 \text { is one of the least developed areas of the entire } \\
\text { regional system, characterized by lack of entrepreneurship. } \\
\text { Cultural activities show a good level of local coordination, } \\
\text { but suffer from lack of identity }\end{array}$ & $\begin{array}{l}\text { The creative reuse of abandoned infrastructures and latent } \\
\text { strengths such as the music industry, museums, archives and } \\
\text { libraries represent a promising direction. }\end{array}$ & 144 & 82 \\
\hline $\begin{array}{l}\text { 12. Colli } \\
\text { Euganei }\end{array}$ & $\begin{array}{l}\text { The Euganean Hills have a high environmental value. It is a } \\
\text { relatively small district in terms of area, population, degree } \\
\text { of socio-economic development. The cultural policies and } \\
\text { actions have only a local impact }\end{array}$ & $\begin{array}{l}\text { The strategy aims to redefine the local development model } \\
\text { enhancing its ties to major urban centers and involving } \\
\text { private stakeholders also from outside of the district }\end{array}$ & 55 & 66 \\
\hline
\end{tabular}

Source: Authors, based on data from DiCE Final Report.

(Fondazione Cariplo, 2007 and Fondazione Cariplo, 2011). The underlying rationale of the program was that promoting dialog, unifying the management of the various cultural activities and connecting the sector with other public and industry systems was going to cut operational costs in the public sector, boost fund-raising, streamline conservation and valorization activities and increase cultural and touristic demand.

The process for developing CDs has involved three phases. The initial analytical phase (2005-2006) has outlined the basic criteria for defining a $\mathrm{CD}$, identified 31 potential areas covering the entire regional territory and issued a call for proposals for feasibility studies (2007). The boundaries of each area were subsequently redefined with key local proponents and potential grantees (see Fig. 2).

The second phase of the project (2008-2010) was aimed at assessing the local political will and capability to participate in the program. After the completion of the feasibility studies, a second selection process led to the co-financing and implementation of $6 \mathrm{CDs}$ 
In the implementation and monitoring phase (20102014), the Foundation followed the program carried out by the Districts through regular monitoring. The program is currently ongoing.

\section{Analytical tools}

A first analytical study was commissioned by the foundation to Politecnico di Milano University. It drew on academic literature and regional policy goals to outline the basic criteria for defining a CD including: (1) Prominence of cultural assets - defined as architectural, artistic, intangible and natural assets, together with museums and collections; (2) Definition of territorial boundaries as common geographical and cultural features (3) Shared cultural identity among local community members (4) the presence of educational institutions at various levels. Alongside these, innovation and networking capacity, diversified cultural offering and the presence of economic organizations that are complementary to heritage appreciation process or benefiting from its positive externalities (fairs, congresses etc.) were identified

\section{(1) Local administration's competence and commitment}

This general framework guided a province-by province qualitative analysis that identified target areas among small and medium communities (in fact, the funding available was assumed to have little impact in larger cities), on the basis of cultural offering, institutional and relational capital emphasizing the abovementioned criteria.

In the second phase of the program, feasibility studies were developed by eleven candidate CDs and they included the analysis of the local conditions, cultural strategy, a list of interventions on the material and intangible heritage accompanied by a communication plan, an outline of a management, governance and financial plan.

\section{Data collection}

Within each CD area, data have been collected from multiple sources, but rely heavily on interviews with key local actors to point out not only the presence of assets and services but also relationships and existing networks. It also highlighted the local organizational capacity and the general socio economic characteristic of the areas.

\section{Spatial analysis of boundaries and spatial configuration}

The preliminary analysis defined CDs by listing a set of municipalities and provinces and the relevant alliances and networks, and the total population. The boundaries were provisional, and allowed local coalitions to propose a different and more accurate delimitation. The 'emergent'

Table 2

The Cultural Districts co-financed by Cariplo Foundation. Description, partners, startup date, total investment and co-funding from Cariplo Foundation in million euro.

\begin{tabular}{|c|c|c|c|c|c|}
\hline Name & Description & Partners & $\begin{array}{l}\text { Startup } \\
\text { date }\end{array}$ & $\begin{array}{l}\text { Total } \\
\text { Investment } \\
(\text { mill. } €)\end{array}$ & $\begin{array}{l}\text { Cariplo } \\
\text { Foundation } \\
\text { investment } \\
\text { (mill. €) }\end{array}$ \\
\hline 1. Valle Camonica & $\begin{array}{l}\text { The rupestrian artistic and archeological } \\
\text { resources of the Valley are UNESCO classified } \\
\text { but underutilized. Stimulating creative } \\
\text { industries is aimed at boosting the cultural } \\
\text { offer and local tourism. }\end{array}$ & $\begin{array}{l}42 \text { Valley Municipalities, The Ministry for } \\
\text { Cultural Heritage and the Arts, Province of } \\
\text { Brescia, ARCUS, Boario Terme, Cultural } \\
\text { associations, Energy businesses associations }\end{array}$ & 01.01.2009 & 12.8 & 3.8 \\
\hline $\begin{array}{l}\text { 2. DOMINUS - Oltrepò } \\
\text { Mantovano }\end{array}$ & $\begin{array}{l}\text { The strategy for this rural area targets the } \\
\text { promotion of local natural and cultural } \\
\text { heritage, emphasizing the food production } \\
\text { chains as main factors that shape the landscape } \\
\text { and reflect the work of the community }\end{array}$ & $\begin{array}{l}\text { Mantua Province, } 13 \text { Municipalities, } \\
\text { Politecnico di Milano, Mantua Agrotourism } \\
\text { Consortium, Mantua Chamber of Commerce, } \\
\text { The Group for Local Action 'Oltrepò } \\
\text { Mantovano', The local library system }\end{array}$ & 01.01 .2011 & 18 & 3.16 \\
\hline $\begin{array}{l}\text { 3. The Province of } \\
\text { Cremona }\end{array}$ & $\begin{array}{l}\text { Music and craftsmanship are central to the } \\
\text { local culture and economy. The District intends } \\
\text { to coordinate the artistic and entrepreneurial } \\
\text { initiatives that are already in place in the music } \\
\text { field, to restore and reuse historic buildings for } \\
\text { activities related to music and build stronger } \\
\text { territorial marketing }\end{array}$ & $\begin{array}{l}\text { Cremona Chamber of Commerce, } 8 \\
\text { Municipalities, The Stradivari Foundation, } \\
\text { Pavia University, Artisan training } \\
\text { organizations, Music and performing arts } \\
\text { foundations and associations }\end{array}$ & 01.01 .2011 & 9 & 2.6 \\
\hline 4. The Gonzaga Palaces & $\begin{array}{l}\text { A network built around the Gonzaga heritage, } \\
\text { this district targets the development of } \\
\text { innovations for built heritage conservation and } \\
\text { cultural production, and of local gastronomy. } \\
\text { The UNESCO Site of Mantua and Sabbioneta } \\
\text { testifies the significance of the local heritage }\end{array}$ & $\begin{array}{l}13 \text { Municipalities, Mantua Chamber of } \\
\text { Commerce, Industries Union, Mantua } \\
\text { Agrotourism Consortium, Politecnico di } \\
\text { Milano, Cultural organizations }\end{array}$ & 01.01 .2011 & 8 & 3.4 \\
\hline $\begin{array}{l}\text { 5. The Province of } \\
\text { Monza and Brianza }\end{array}$ & $\begin{array}{l}\text { Innovation in conservation technology and } \\
\text { integration with the construction industry and } \\
\text { higher education institutions are central goals } \\
\text { of this District. Business incubators are } \\
\text { planned to locate in heritage structures, } \\
\text { integrated with cultural uses }\end{array}$ & $\begin{array}{l}5 \text { Municipalities, Industries Associations, } \\
\text { Monza and Brianza Chamber of Commerce, The } \\
\text { National Confederation for artisanship and } \\
\text { SME, Construction industry associations, } \\
\text { Training and research institutions }\end{array}$ & 01.01 .2011 & 9 & 3.66 \\
\hline 6. Valtellina & $\begin{array}{l}\text { The District promotes the culture of Valtellina } \\
\text { as a communication route between Italy and } \\
\text { Northern Europe. In addition it promotes local } \\
\text { architecture and landscape, integrating } \\
\text { culinary tradition with new management and } \\
\text { communication strategies }\end{array}$ & $\begin{array}{l}\text { Province of Sondrio, } 7 \text { Municipalities, Energy } \\
\text { businesses associations, Lending Institutions, } \\
\text { Pavia University, The Food District, The } \\
\text { Valtellina Group for Local Action }\end{array}$ & 01.07.2011 & 8 & 3.58 \\
\hline
\end{tabular}




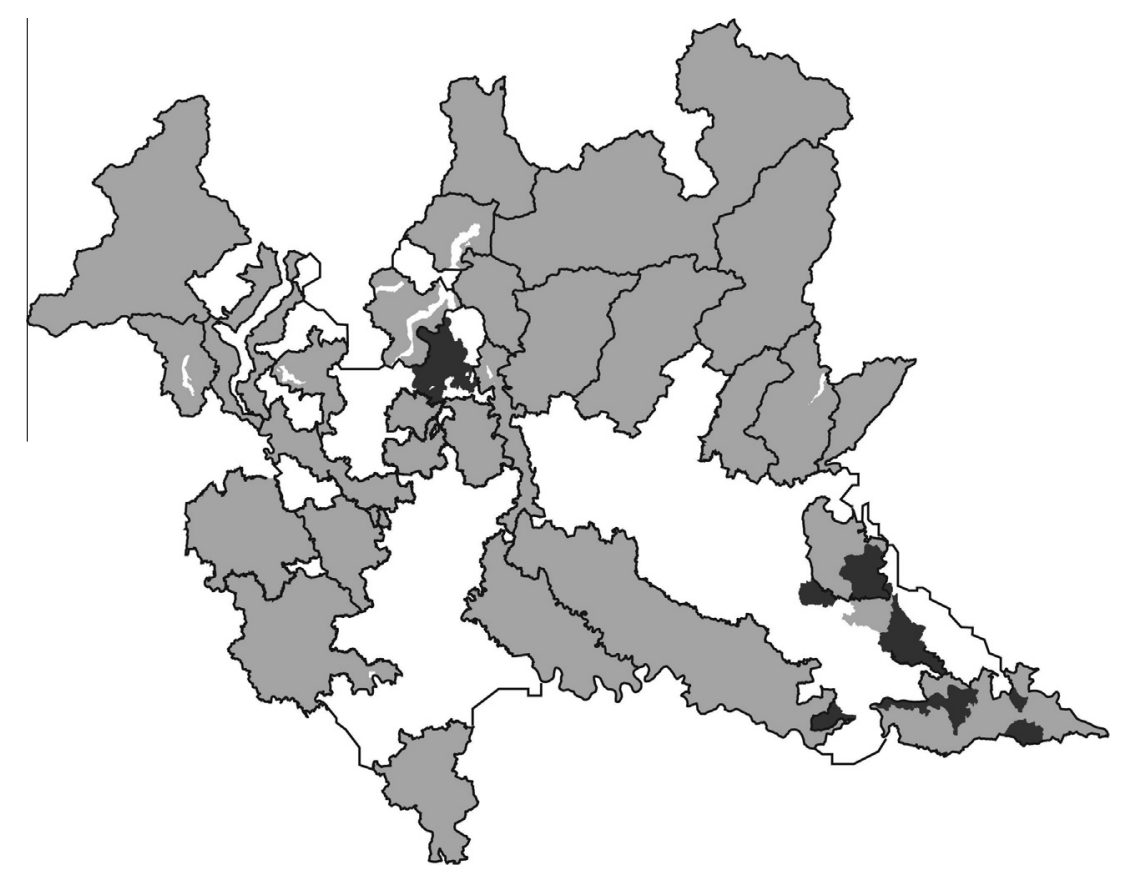

Fig. 2. The Cultural Districts envisioned in the pre-feasibility study. The study covered Lombardy and the provinces of Novara and Verbano-Cusio-Ossola in Piedmont.

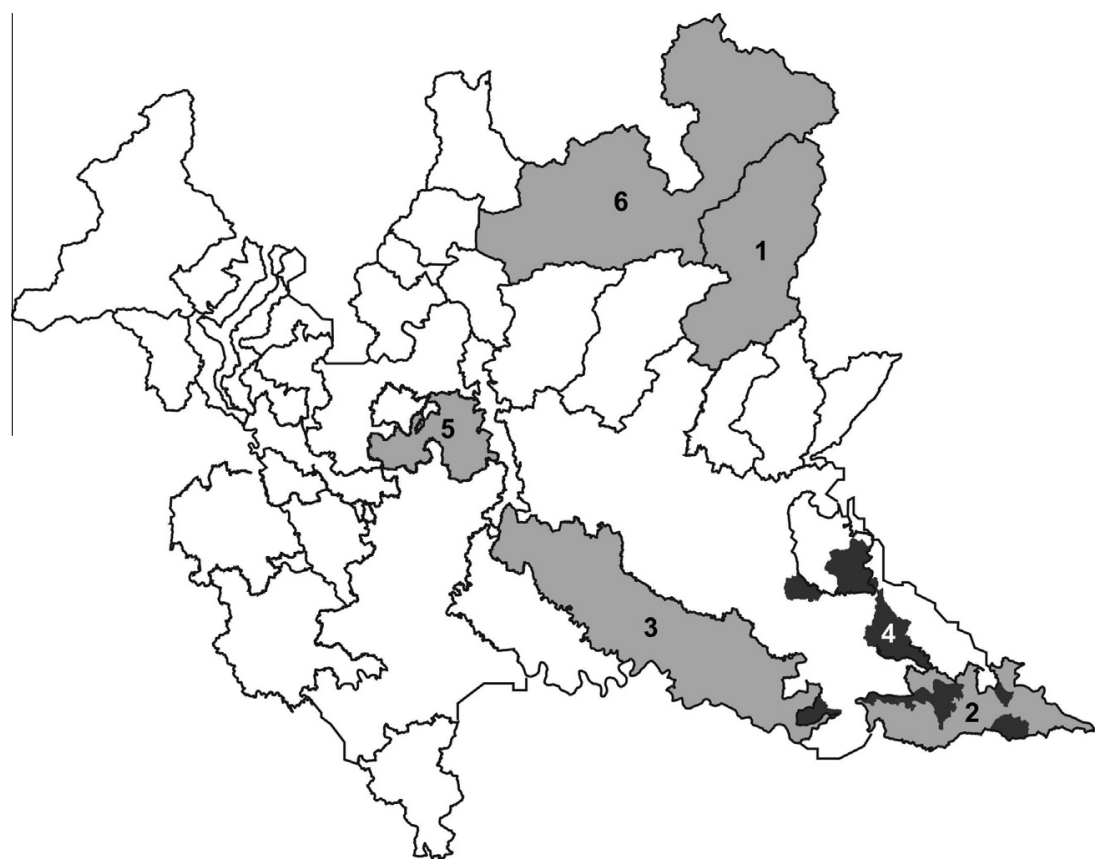

Fig. 3. The six Cultural Districts co-financed by Cariplo Foundation.

CDs identified in the preliminary analysis varied largely in scale and total population, ranging from provincial to subprovincial level.

\section{Cultural market and feasibility studies}

The analysis compiled a comprehensive assessment of the cultural supply and demand in the relevant areas. They emphasized the diversity of the cultural supply and the interrelationships between public projects, cultural and tourism industries, and education. Each CD feasibility study performed a SWOT Analysis. The governance model, financial feasibility and management plan were decisive for the candidate CDs to be funded by Cariplo.

\section{Process management and the involvement of local actors}

The Foundation cooperated with a range of regional and local institutions and actors throughout the entire process. Local administrations were engaged since the early phase 
of researching and mapping cultural systems. Once the vision for the CD program was articulated and communicated, local actors defined alliances and designed their own strategy. The program also encouraged the participation of major economic stakeholders and cultural entrepreneurs. During the implementation phase, a participative monitoring and evaluation process was undertaken, encouraging representatives of the newly constituted CDs to define indicators.

Cariplo Foundation, together with the involved academic staff, disseminated the program vision and the data collected through both formal and informal channels, organizing multiple meetings with local representatives and public seminars throughout the entire length of the program. A website dedicated to the program was established. Monitoring and evaluation data, on the other hand, circulated between the districts but were not disclosed to the public. In all phases both the Foundation and a dedicated evaluation team assisted the involved proponents.

\section{Funding and monitoring}

The program provided funding both for studying the feasibility of a CD - up to 60,000 Euro, or 70\% of the research costs -, and for their implementation - up to 4 million Euro, or $50 \%$ of the total costs. The Foundation co-funded 6 CDs with a total of 20.2 million Euro. This amount was matched by the 6 districts with 44.6 million Euro raised locally, mostly from public sources.

Each $C D$ has undergone a regular assessment of the implementation process. Districts were invited to work with the evaluation team to design indicators and collect data on the use and beneficiaries of individual projects. A final study will provide a counterfactual impact assessment (see Table 2).

\section{Analysis and findings}

The two initiatives for CDs in Veneto and Lombardy show peculiar spatial features and political dynamics that reflect two distinct approaches to regional CDs in Italy. A fundamental difference between them is the conceptualization of the very notion of the $C D$, which impacted the cultural mapping process and the policy measures involved. The Veneto Region initiative interpreted CDs as emerging clusters that should provide an underlying fabric for cultureled development. The Cariplo Foundation decided to focus precisely on their mobilization, formal recognition and direct financing. Both initiatives were aimed at linking heritage preservation, creative production and consumption to a larger set of on-going local economic and social policies through coordination and integration. In both cases, the quality of local cultural and creative production was a stated goal, as was collective learning and change towards a better governance of heritage and creative indus-tries. In addition, they both started out by taking into consideration a given region (according to the territory of the Veneto Region and the area of action of Cariplo Foundation: Lombardy and the Verbania and Novara Provinces). In Veneto, the analysis covered the entire territory, while in Lombardy it explicitly targeted the non-metropolitan territory.

The two initiatives saw cultural mapping as the essential step for mobilizing the local actors to develop and innovate their cultural system. In both cases, the mapping task was delegated to prominent universities: Politecnico di Milano in Lombardy and IUAV University in Veneto. Both focused primarily on public cultural assets. The difference in methods and approach was, however, significant. The Veneto Region study had a top-down synoptic approach, based on quantitative data analysis (including a very wide range of cultural facilities and activities which goes well beyond standard international classifications). Here the conceptual underpinning of a CD was not based in agglomeration, nor in a system of relationships, but in a complex interpretation of cultural specialization that took into consideration natural and anthropic features. The cultural mapping exercise was therefore used to divide the entire regional territory according to these cultural matrices (see Fig. 1). Conversely, the Cariplo analysis did highlight notable local assets, but focused on relational systems and institutional capacity, outlining loose sketches of the existing situation, relying on the help of key local informants to assess the local capacity to network and mobilize. Cariplo avoided a narrow and sectoral understanding of cultural clusters, directed strictly at creative industries, tourism, or the arts, heritage and conservation. It proved to be a way to collect usable knowledge for subsequent policymaking and catalyzing political consensus.

The different spatial arrangements that derived resulted in the coverage of the whole regional territory in the case of Veneto and in a focus on marginal, but culturally rich areas in Lombardy (as shown respectively in Fig. 1 and 3). This partially depends on the operative goals the two programs had. In addition, we can notice that Veneto paid less attention to the integration of cultural policy instruments with existing spatial planning documents and processes.

Significant considerations can also be derived from the comparison of the promoting entities, the time-frame and the political support of the two initiatives. The different nature of the promoters, i.e. the Veneto Regional Government and the Cariplo Foundation can to some extent explain the time-frame of the initiatives, which varied respectively from 3 , to 8 years - reflecting a one-time European funding opportunity in the first case and the more stable commitment of the foundation in the other. The continuity of political support in developing CDs proved to be necessary in both cases, but the long-term expectation of concrete results triggered by collective learning and the collaborative implementation of projects required a stable organization that could last longer than one political term of office ( 5 years).

Finally the approaches to financing were completely different. In the Veneto case, districts were expected to take the CDs further on their own, which did not happen. Cariplo, on the other hand, provided significant financial incentives for all phases of mapping, strategy design, and implementation, expecting that the CDs should trigger selffinancing afterwards (the financial incentives provided by the Cariplo Foundation ranged between 2.6 and 3.8 
million euro for each District; they were matched by each CD with funds from Municipalities, Provinces or private donors, ranging from 8 million euro to 18 million euro).

\section{Conclusions}

This paper addresses an often expressed concern in the broader international debate on $\mathrm{CD}$, regarding the need for greater conceptual clarity in the use of the term and its underlying conceptual and operational implications (e.g., Cooke and Lazzeretti, 2008; Santagata, 2002; Stern \& Seifert, 2007). This issue has been previously tackled in literature by various distinctions between $\mathrm{CD}$ as creative industry clusters and $\mathrm{CD}$ as geographical concentrations of cultural assets, between spontaneous and planned $\mathrm{CD}$, or between $\mathrm{CD}$ and related terms such as 'cultural quarters' or 'cultural clusters'. Nevertheless, the key challenge for both academics and policy makers has remained the distinction between, and the passage from, an abstract-analytical approach to $\mathrm{CD}$ - as exemplified by various forms of cultural mapping - and policy intervention, as conditioned by different contexts and the corresponding layered opportunities provided by European, regional and local frameworks.

Our paper illustrates the facets of this particular problem in the Italian context, and highlights the distinctions between the two different acceptations of $C D$ under several aspects, across two different cases: policy goals, analytical approach, process management, and policy instruments. The analysis points out several key conclusions.

Firstly, this topic is given considerable attention in national policymaking in Europe - though it has a high territorial variety according to the specific geographical context and policy contents - without any clear reference to specific research and policy traditions. The literature and rich experience of industrial districts constitutes today an important background for the Italian cultural cluster debate and policymaking (Beccattini, 2003; Bagnasco, 1977; Putnam, 1993). As we know, industrial district stud-ies gave birth to relevant policy experimentations for local development in Italy (Trigilia, 2005). Although one can find different understandings and experimentations of cultural clusters in Italy, we can confirm this 'genealogy' for the Italian case and call for further studies in other European countries.

Secondly, this paper contributes to the debate with an indepth study of two CD initiatives in Italy, providing evidence of and directing the attention towards the difference between two acceptations of $\mathrm{CD}$ under different perspectives (goals, analytical process, etc.). In several Italian cases, the concept of the CD was successfully used in analytical terms. Confirming Santagata's position (2002), the simplistic interpretation of the $\mathrm{CD}$ as a ready-made policy measure can induce effects that are well below the expectations (this is now evident in other fields of cultural economy planning: Grodach, 2013). The conceptual decoupling of what constitutes an agglomeration of cultural producers and what constitutes a system of policy relationships seems necessary not only in the academic debate but also, and most importantly, to cultural policy makers.

Thirdly the mapping undertaken in the two cases showed that the knowledge produced relied on different paths (top-down in Veneto and mixed top-down bottom-up in Lombardy), and the types of information and their relevance for action depended on an a priori conceptualization of CDs, rather than specific policy goals alone. The comparison of the two initiatives makes it evident that complex cultural mapping can be achieved by policymakers without systematically involving local stakeholders (Arnaboldi \& Spiller, 2011). On the other hand, the planning of concrete actions and their implementation bene-fits extensively from the commitment and knowledge resources of local actors. This is consistent with other find-ings that previously highlighted a bottom-up approach in developing CDs (Mommaas, 2004; Stern and Seifert, 2010).

Fourth, regarding the prominent role of experts in cultural policy making, the high competence in cultural heritage matters and the prompt translation of an analytical concept such as the district into cultural policy guidelines have clearly been a two-edged sword for Italy. Often, reputed scholars with broad opinion-making influ-ence have persuaded public and nonprofit institutions to undertake CDs initiatives with a limited budget, which, in several occasions, was almost entirely consumed by the analysis itself! This point is systematically removed from international debates, probably being perceived as uncomfortable knowledge for scholars and policy experts (Flyvbjerg, 2013).

Fifth, CD policy displays its development effects in the long term. Typically, political terms of office are shorter than the CDs study and start-up period. These sorts of programs tend to survive the end of political terms only if supported by a strong political commitment or by organizations that are not very permeable to (local) political pressure and change. This aspect, as well as the previous, did not obtained any attention in the cultural policy debate.

Besides the Italian peculiarities and constraints, one must notice that these considerations are relevant for European policymaking with reference to cultural heritage and creative industry policy (Santagata, 2014). In order to improve the debate regarding $C D$ analysis and policymaking in Europe, significant consideration should be given to critical policy conditions, such as the agenda, timeframe and political interaction implied, the type of knowledge produced and used. According to our work, the Italian experience definitely needs further research, whether this means higher attention of international scholars or stronger presence of the Italian scholars in international debates.

\section{References}

Andres, L., \& Chapain, C. (2013). The integration of cultural and creative industries into local and regional development strategies in Birmingham and Marseille: Towards an inclusive and collaborative governance? Regional Studies, 47(2) $161-182$.

Arnaboldi, M., \& Spiller, N. (2011). Actor network theory and stakeholder collaboration: The case of Cultural Districts. Tourism Management, 32(3), 641-654.

Bagnasco, A. (1977). Tre Italie. La problematica territoriale dello sviluppo economico italiano. Bologna: Il Mulino.

Beccattini, G. (2003). From industrial districts to local development: An itinerary of research. Cheltenham, UK, and Northampton, MA: Edward Elgar.

Bertacchini, E., \& Borrione, P. (2013). The geography of the Italian creative economy: The special role of the design and craft-based industries. Regional Studies, 47(2), 135-147.

Bertacchini, E., \& Santagata, W. (Eds.). (2012). Atmosfera creativa. Un modello di sviluppo sostenibile per il Piemonte fondato su cultura e creatività. Bologna: Il Mulino. 
BOP Consulting (2010). Mapping the creative industries: A toolkit. London: British Council.

Brooks, A., \& Kushner, R. (2001). Cultural Districts and urban development. International Journal of Cultural Management, 3(2), 4-15.

Calcagno, M., Lusiani, M., Panozzo, F. (2012). Rhetoric and practice of Cultural Districts as a model of governance: Empirical evidence from the Veneto region.

Ca' Foscari Department of Management Working Paper, 19/2012, 1-29. Chapain, C.,

Clifton, N., \& Comunian, R. (2013). Understanding creative regions:

Bridging the gap between global discourses and regional and national contexts. Regional Studies, 47(2), 131-134.

Colbert, F. (2011). Cultural policies and creative cities: Some insights. City, Culture and Society, 2(1), 1.

Comunian, R. (2011). Rethinking the creative city the role of complexity, networks and interactions in the urban creative economy. Urban Studies, 48(6) 1157-1179.

Cooke, P. (2005). Culture, clusters, districts and quarters: some reflections on the scale question. Sviluppo Locale, 26, 7-30.

Cooke, P., \& Lazzeretti, L. (2008). Creative cities, cultural clusters and local economic development. Cheltenham: Edward Elgar.

Council of the European Union (2007). Contribution of the cultural and creative sectors to the achievement of the Lisbon objectives - Adoption of the council

conclusions. Cult 29, 9021(07). Brussels: CEU.

DCMS (1998). The creative industries mapping document. London: Department of Culture, Media and Sport.

De Luca, S., \& Rotondo, S. (Eds.). (2005). Le risorse culturali. Rome: Formez.

European Commission (2010). Green paper: Unlocking the potential of cultural and creative industries. COM (183). Brussels: European Commission.

European Commission (2013). Creative Europe; support programme for Europe's cultural and creative sectors from 2014. Available from: http://ec.europa.eu/ culture/creative-europe/index_en.htm.

Evans, G., \& Foord, Jo. (2008). Cultural mapping and sustainable communities: Planning for the arts revisited. Cultural Trends, 17(2), 65-96.

Flyvbjerg, B. (2013). How planners deal with uncomfortable knowledge: The dubious ethics of the American planning association. Cities, 32(1), 157-163.

Fondazione Cariplo (2007). Linee guida. Come realizzare uno studio di fattibilità operativa per la progettazione di un distretto culturale. Milano: Fondazione Cariplo.

Fondazione Cariplo (2011). I distretti culturali. In I musei italiani e i distretti culturali: punti di forza e di debolezza. Aspen Institute Italia.

Frost-Kumpf, H. A. (1998). Cultural Districts: The arts as a strategy for revitalizing our cities. USA: Americans for the Arts.

Gibson, C., Brennan-Horley, C., \& Warren, A. (2010). Geographic information technologies for cultural research: Cultural mapping and the prospects of colliding epistemologies. Cultural Trends, 19(4), 325-348.

Gibson, L., \& Stevenson, D. (2004). Urban space and the uses of culture. International Journal of Cultural Policy, 10(1), 1-4.

Grodach, C. (2013). Cultural economy planning in creative cities: Discourse and practice. International Journal of Urban and Regional Research, 37(5), 1747-1765.

Higgs, P., \& Cunningham, S. (2008). Creative industries mapping: Where have we come from and where are we going? Creative Industries Journal, 1(1), 7-30.

KEA (2009). The impact of culture on creativity. Brussels: KEA European Affairs.

Lazzeretti, L. (2012). The resurge of the 'societal function of cultural heritage'. An introduction. City, Culture and Society, 3, 229-233.

Lazzeretti, L., Boix, R., \& Capone, F. (2008). Do creative industries cluster? Mapping Creative Local Production Systems in Italy, Working Papers 5/08, Department of

Applied Economics at Universitat Autonoma of Barcelona.

Le Blanc, A. (2010). Cultural Districts, a new strategy for regional development? The South-East cultural district in Sicily. Regional Studies, 44(7), 905-917.

Lee, D., \& Gilmore, A. (2012). Mapping cultural assets and evaluating significance: Theory, methodology and practice. Cultural Trends, 21(1), 3-28.

Lorenzini, E. (2011). The extra-urban cultural district: An emerging local production system. Three Italian case studies. European Planning Studies, 19(8), 1441-1457.

Matarasso, F. (1999). Towards a local culture index: Measuring the cultural vitality of communities. Stroud UK: Comedia.

Miles, S., \& Paddison, R. (2005). Introduction: The rise and rise of culture-led urban regeneration. Urban Studies, 42(5/6), 833-839.

Mizzau, L., \& Montanari, F. (2008). Cultural Districts and the challenge of authenticity: The case of Piedmont, Italy. Journal of Economic Geography, 8, 651-673.
Mommaas, H. (2004). Cultural clusters and the post-industrial city: Towards the remapping of urban cultural policy. Urban Studies, 41(3), 507-532.

Moon, M. J. (2001). Cultural governance: A comparative study of three Cultural Districts. Administration and Society, 33(4), 432-454.

Ponzini, D. (2009). Urban implications of cultural policy networks. The case of the Mount Vernon Cultural District in Baltimore. Environment and Planning C: Government and Policy, 27(3), 433-450.

Ponzini, D. (2011). Large scale development projects and star architecture in the absence of local politics: The case of Abu Dhabi, UAE. Cities, 28(3), 251-259. Pratt, A. C. (1997). The cultural industries production system: a case study of employment change in Britain, 1984-91. Environment and Planning A, 29,

1953-1974.

Pratt, Andy C. (2004). Mapping the cultural industries: regionalization; the example of south-east England. In D. Power \& A. J. Scott (Eds.). Cultural industries and the production of culture (pp. 19-36). London: Routledge.

Pratt, A. C. (2008). Cultural commodity chains, cultural clusters, or cultural production chains? Growth and Change, 39(1), 95-103.

Pratt, A. C. (2012). The cultural and creative industries: Organisational and spatial challenges to their governance. Die Erde, 143(4), 317-334.

Putnam, R. (1993). Making Democracy Work. Princeton: Princeton University Press.

Raco, M., \& Gilliam, K. (2012). Geographies of abstraction, urban entrepreneurialism, and the production of new cultural spaces: the West Kowloon Cultural District, Hong Kong. Environment and Planning A, 2012(44) 1425-1442.

Roodhouse, S. (Ed.). (2010). Cultural quarters: Principles and practice. London: Intellect Books.

Sacco, P. L., \& Crociata, A. (2012). A conceptual regulatory framework for design and evaluation of complex, participative cultural planning strategies. International Journal of Urban and Regional Research.

Sacco, P. L., Tavano Blessi, G., \& Nuccio, M. (2008). Culture as an engine of local development processes: system-wide Cultural Districts. Working paper. IUAV University. Available from: http://www.sociologia.unimib.it/DATA/ Insegnamenti/14_3680/materiale/wp_2008_05.pdf.

Sacco, P. L., Ferilli, G., \& Lavanga, M. (2007). System-wide Cultural Districts: A review of reference cases. Venice: Mimeo.

Sacco, P. L., Ferilli, G., \& Tavano Blessi, G. (Eds.). (2012). Cultura e sviluppo locale. Verso il distretto culturale evoluto. Bologna: Il Mulino.

Sacco, P. L., \& Tavano Blessi, G. (2005). Distretti Culturali Evoluti e Valorizzazione del Territorio. Global and Local Economic Review, 7(1), 7-42.

Santagata, W. (2002). Cultural Districts, property rights and sustainable economic growth. International Journal of Urban and Regional Research, 26(1), 9-23.

Santagata, W. (Ed.). (2009). Libro bianco sulla creatività. Per un modello italiano di sviluppo. Milan: Università Bocconi Editore.

Santagata, W. (2014). Il Governo della Cultura. Promuovere Sviluppo e Qualità Sociale. Bologna: Il Mulino.

Scott, A. J. (1997). The cultural economy of cities. International Journal of Urban and Regional Research, 21(2), 323-339.

Scott, A. J. (2004). Cultural-products industries and urban economic development: Prospects for growth and market contestation in global context. Urban Affairs Review, 39(4), 461-490.

Stern, M. J., \& Seifert, S. (2007). Cultivating "natural" Cultural Districts. Philadelphia: The Reinvestment Fund.

Stern, M. J., \& Seifert, S. (2010). Cultural clusters: The implications of cultural assets agglomeration for neighborhood revitalization. Journal of Planning Education and Research, 29(3), 262-279.

Stolarick, K., Hracs, B. J., \& Florida, R. (2010). Occam's curse, dialectics, and the creative city. City, Culture and Society, 1(4), 175-177.

Tepper, S. J. (2002). Creative assets and the changing economy. Journal of Arts Management, Law and Society, 32(2), 159-166.

Trigilia, C. (2005). Sviluppo locale: un progetto per l'Italia. Rome and Bari: Laterza.

UNDP, UNCTAD (2010). Creative economy report. Geneva/New York: UNCTAD/UNDP.

UNESCO (2006). Understanding creative industries: Cultural statistics for public-policy making. Paris: UNESCO, Global Alliance for Cultural Diversity.

Valentino, P. A. (2003). Le trame del territorio. Politiche di sviluppo dei sistemi territoriali e distretti culturali. Milano: Sperling \& Kupfer.

Wilks-Heeg, S., \& North, P. (2004). Cultural policy and urban regeneration: A special edition of local economy. Local Economy, 19(4), 305-311.

Wojan, T. R., Lambert, D. M., \& McGranahan, D. A. (2007). The emergence of rural artistic havens: A first look. Agricultural and Resource Economics Review, 36(1), 53 